\title{
Academics' perceptions of continuous and collaborative curriculum review: an Australian case study
}

Bird, J., van de Mortel, T.F., Holt, J., Walo, M.

\begin{abstract}
Tourism and hospitality educators face particular challenges in meeting current national and international pressures and requirements for accreditation of their curricula within national standards frameworks.
\end{abstract}

Conventional curriculum design and review processes may not suffice in meeting these challenges. In other disciplines and subject areas innovative models of continuous and collaborative curriculum design processes are responding to these challenges, yet the literature on this topic is absent in tourism and hospitality education.

This case study investigates academics' experiences and perceptions of a continuous and collaborative curriculum review process introduced in a School of Tourism and Hospitality Management (STHM) at an Australian regional university.

The study found that academics valued the opportunities the process afforded to improve the curriculum from a whole-of-program perspective. The collaborative nature of the process, the opportunities for scholarship of teaching outcomes and the building of multidisciplinary relationships were also seen as positive outcomes. Concerns included a lack of clarity regarding procedures for acting upon matters identified during review and challenges associated with collaboration across multiple campuses.

Key words: curriculum, tourism and hospitality education, continuous curriculum review, collaboration, academic perceptions. 


\section{Introduction}

Like all contemporary curricula in higher education, tourism and hospitality curricula face a myriad of pressures. Dredge, Benckendorff, Day, Gross, Walo, Weeks \& Whitelaw (2013, p. 99) outline the particular 'miasma' of international and national pressures impacting on tourism and hospitality education in Australia and alert educators to the fact that 'the need for closer attention to degree content, delivery, and academic standards is becoming increasingly critical.' These pressures include: credit recognition and transferability, funding linked to performance accountability, the design, maintenance and management of whole-of-program curriculum maps of graduate attributes, subject/discipline standards, threshold learning outcomes, learning-centred pedagogies and student assessment. External professional accreditation requirements, technologies that enable new and multiple modes of delivery across multiple delivery sites, and the volume and pace of production of new knowledge are additional factors in this complex mix. Conventional approaches to curriculum design and review may no longer suffice in responding to this environment.

Higher education institutions dedicate considerable effort and resources to the design of new program, and the subsequent three or five yearly formal quality assurance program reviews. However, the space in between these reviews typically remains the private and individual domain of teaching academics. Various authors (see for example Fisher, Fairweather \& Amey , 2003; Briggs , 2007; van de Mortel \& Bird, 2010; Hubball \& Gold ,2007) have identified the risks to curriculum cohesion and alignment associated with this privatized space. These risks include: curriculum drift, curriculum fragmentation, lack of academic collaboration, and no vision of the 'whole' curriculum as experienced by learners. 
New and innovative approaches to curriculum development and review are designed to address the above risks as well as improving curricula and academic practice.

There appear to be no previous tourism and hospitality case studies reporting innovative processes of continuous and collaborative curriculum review (CCCR). This study aims to fill this gap by investigating a continuous curriculum review process implemented within the School of Tourism and Hospitality (T\&HM) at Southern Cross University (SCU). This School offers linked undergraduate programs in tourism, hospitality and conventions and events management across four Australian campuses and two international partner campuses.

In brief the CCCR process involves the continuous and collaborative review of undergraduate subjects by teaching academics, the Program Coordinator and academic support staff and librarians. The process occurs biannually after each semester. Academics meet in teaching teams (eg academics teaching first year subjects) that also include teaching and learning staff, academic skills support staff and librarians. Teams collectively review their subjects' quantitative and qualitative student data. Teams share issues and concerns about grades, student feedback on teaching, attrition, academic integrity, assessment, content, and students at risk. Recommendations are made to individual academics for changes to specific subjects, the Program Director when suites of subjects were involved, or the Head of School for issues of resourcing, staffing, governance or management. All documentation contributes to an evidencebased -program performance portfolio that in turn informs the formal five yearly program review.

The purpose of this study is to investigate academics' perceptions of this continuous curriculum review process, their affective response to it, and their perception of the value and outcomes of the process. 


\section{Literature Review}

This paper draws on the conceptualisation of curriculum in higher education described by Barnett and Coate (2004:44) who define the term curriculum, 'in significant part at least, as the set of organised processes and materials that, intentionally and unintentionally, are put before students by their educators.' They describe three levels at which curricula are designed: a) whole of discipline or subject area (for example subject benchmarks and standards), b) new programs designed-in-advance for initial accreditation, and c) the ongoing design-in-action of existing programs through the session by session, week by week and day by day adjustments of academics. At this third level Barnett \& Coate (2004, p. 51) conceive of the curriculum as dynamic and in flux, always a 'curriculum in process'.

\section{The status quo}

Typically higher education curriculum design and review processes are driven by individual institutions' policies for new program approval and subsequent cycles of program review, which in turn respond to the quality and accreditation requirements of relevant national standards bodies such as the Tertiary Education Quality Standards Agency (TEQSA) in Australia and the Quality Assurance Agency (QAA) in the United Kingdom. These two points in the lifecycle of a curriculum - initial approval and subsequent review - are policy-driven, formal and systematic. They are stakeholder inclusive, scrutinized, documented, evidence-based and resource intensive. Program review policies usually require formal reviews every three to five years. Yet requirements for ongoing review processes within these three to five year cycles, at Barnett \& Coate's (2004) 'design-in-action' level, do not command the same attention or resources. 
Traditional curriculum design and review processes have attracted a range of criticisms. One large UK study (cited in Dempster, Benfield \& Francis, 2012) found that current curriculum design practice lacked flexibility, systems for the regular updating of course content, collaboration, and the student perspective. Barnett and Coate (2004, p. 45) argue that 'the idea of the process of curriculum design subsisting in a timeframe in which a curriculum is first designed and then put into action has to be abandoned.' Hubball \& Gold (2007:11) argue that review processes amount to 'five-year summative data gathering frenzies ' and should rather be considered as 'scholarly, formative and developmental'.

In traditional curriculum design and review processes, responsibility for the design-inaction space typically lies with individual academics who engage (or not) in daily adjustments to their subjects within the private and autonomous domain traditionally afforded academics. Fisher, Fairweather \& Amey (2003) investigated the tension between individual and collective responsibility for the curriculum in the design-inaction space. They argue that the tradition of academic autonomy (and its associated academic freedom) supports individualistic academic effort in relation to curriculum review and renewal; that collective responsibilities generally are not rewarded or acknowledged as they fall outside of job descriptions; that individual improvements remain inside the privacy of teaching spaces; and that aggregating individual efforts as a measure of quality in teaching, learning and curriculum is insufficient in fulfilling an academic department's curricular obligations.

Both Hubball and Gold (2007) and Briggs (2007) point out that one of the consequences of this private and individualized design-in-action space is that the curriculum is at risk of becoming fragmented rather than cohesive, and that individual units/subjects become 'islands unto themselves' (Hughes, 2007, p. 109). From the students' 
perspective, the curriculum can become a 'set of often fragmented and unconnected individual course learning experiences.' It becomes the students' responsibility to 'make sense of the whole (if at all)' (Hubball \& Gold, 2007, p. 8).

\section{Innovations}

As far back as 1985 the Association of American Colleges and Universities called for departments to take responsibility for curriculum issues and for academics to collaborate closely in the design and renewal of cohesive programs of study such that individual academics move 'to a broader sense of communal responsibility and ownership of "our" students and "our" curriculum" (cited in Briggs, 2007, p. 677).

The last decade has seen an emergence of a fresh interest in new curriculum design and review processes that better respond to the contemporary demands on curricula and those who teach and manage them. In 2007 the e-Journal New Directions in Teaching and Learning dedicated a special issue to this topic under the title 'Curriculum Development in Higher Education: Faculty-Driven Processes and Practices'. The issue includes a variety of case studies of innovative processes of curriculum design and review in North American universities. These and a collection of Australian case studies (see for example Bath, Smith, Stein \& Swann, 2004; van de Mortel, Bird, Holt \& Walo, 2012; Radloff, 2004) demonstrate a rich diversity of innovative processes across many disciplines and fields of study in higher education.

Despite their diversity innovative curriculum design and review processes share a number of common characteristics. They are: continuous in that they attempt to fill the gap between the original design of a program and the formal review cycles required by their institution; collaborative in that they involve academics and sometimes students in reviewing/renewing the curriculum together; multidisciplinary in that they include 
other staff such as teaching and learning advisors, academic student support advisors, librarians and learning technologists; and scholarly in that they are processes of enquiry that involve framing questions, analyzing data and applying new understandings.

The new models draw on various theoretical frameworks and empirical studies, the most common being: how professionals, and in particular academics, learn (Knight, 2006; Eraut, 1994), action learning (Argyris, 1985), communities of practice (Wegner, 1998), quality improvement (Deming, 1982), and program evaluation models (Kirkpatrick \& Kirkpatrick, 2006).

The findings from the research on innovative models of continuous and collaborative curriculum review suggest a variety of positive outcomes including benefits to student learning and the student experience (Beetham, 2009; van de Mortel \& Bird, 2010; Harper \& Lattuca, 2010); the quality of the curriculum through ensuring currency of content and a responsive curriculum (Beetham, 2009, van de Mortel et al., 2012) and preventing curriculum drift and protecting curriculum cohesion (Hubball \& Gold, 2007, van de Mortel \& Bird, 2010); and academic practice by providing professional learning to academics in curriculum, teaching and assessment (Marlowe, Wargo \& Kelley, 2012; Beetham, 2009; Bath et al., 2004; Johns \& Henwood, 2009), increasing academics' agency and ownership of whole programs (Radloff, 2004; Keogh, Fourie, Watson \& Gay, 2010); developing curriculum leadership capacity (Keogh et al., 2010; van de Mortel \& Bird, 2010); and improving scholarship of teaching (Hubball \& Gold, 2007).

\section{Tourism, hospitality and event management curriculum}

The particular nature and history of tourism, hospitality and event management education, and its relative youthfulness as a subject area or discipline, may see it less 
well prepared to meet the challenges of curriculum design and review than are other disciplines and subject areas. There are a number of possible reasons for this.

Firstly, tourism, hospitality and event management are multidisciplinary fields of study (Whitelaw, Benckendorff, Gross, Mair, \& Jose, 2015). Many undergraduate programs are taught as combined degrees with arts, social science and business schools where the curriculum is taught by a multidisciplinary team of lecturers, only some of whom are tourism experts (Whitelaw et al, 2015; Fidgeon, 2010). These conditions place considerable stress on maintaining curriculum cohesion and alignment over time.

Secondly, unlike professions like law, nursing or accountancy, there is no professional accreditation body that sets requirements for the knowledge and skills graduates require of a tourism, hospitality and event management curriculum, and that scrutinises and approves the curriculum accordingly. In Australia, the recently launched Tourism Hospitality and Events Standards (2015) do provide benchmarks for minimum threshold learning outcomes for students graduating from tourism, hospitality and event management programs. Unlike the equivalent Subject Benchmarks in the UK, the Australian Standards do not specify core curriculum content.

Thirdly, studies (Stuart, 2002; Fidgeon, 2010) have reported a tendency towards individualism amongst tourism and hospitality academics. Stuart (2002) in her New Zealand study of 27 lecturers' perceptions of critical influences on tourism undergraduate degrees highlights this characteristic:

'the trend which has emerged for lecturers to concentrate their efforts on course [unit/subject] rather than programme development, could have implications for the subject's wider development as a cohesive curriculum' (p.10). 
Fourthly, whilst it is clear that tourism and hospitality educators are engaged in robust and scholarly debates about curriculum content (Dredge et al., 2012), less evident are scholarly investigations of innovative curriculum design and review processes that may assist departments to meet current and pending demands on their curricula.

\section{Curriculum cohesion and alignment}

Program level threshold learning outcomes, standards or benchmarks require careful attention to curriculum cohesion and alignment, both vertical and horizontal. A coherent and aligned curriculum

\footnotetext{
'refers to an academic program that is (1) well organized and purposefully designed to facilitate learning, (2) free of academic gaps and needless repetitions, and (3) aligned across lessons, courses, subject areas, and grade levels. ' (The Glossary of Education Reform at http://edglossary.org/coherentcurriculum/)
}

Alignment occurs between all the elements of the curriculum, including learning outcomes, content, assessment, learning and teaching resources, and pedagogy. Vertical alignment refers to the structuring and sequencing of learning such that students are properly prepared for progression throughout a program. Horizontal alignment refers to the structuring and sequencing of concurrent subjects that are designed at a particular standard and cohere as an overall learning experience. A coherent, aligned curriculum requires ongoing collaboration between its teachers. The continuous and collaborative curriculum review process investigated in this study aimed to achieve this through the systematic bringing together of academics who have a commitment to a shared curriculum. 


\section{Methods}

\section{Research design and data analysis}

This study is a case study conducted at one Australian university. A qualitative research design was used to investigate academics' perceptions of the continuous curriculum review process. Three focus groups utilizing open-ended questions were conducted with academic staff from four university campuses. The duration of focus groups ranged from 50 to 64 minutes. An experienced external facilitator conducted each focus group interview. Focus group discussions were audiotaped and transcribed with participants' permission and the external facilitator de-identified the data prior to the researchers accessing it.

The qualitative software analysis program NVIV09 (QSR International, 2011) was used to conduct a thematic analysis of the data. According to Braun and Clarke (2006, p. 79), thematic analysis is an 'analytic method for identifying, analysing and reporting patterns (themes) within data.' It can be used to organise and describe the data, and interpret aspects of the phenomenon under study (Boyatzis, 1998). Data analysis followed the major steps in the process described by Braun and Clark (2006) which include: reading and re-reading the transcripts, generating initial codes, searching, reviewing, defining and then naming themes, and reporting on the themes with supporting extract examples. Each of the four researchers independently conducted an analysis and differences were resolved by discussion.

\section{Ethics approval}

Ethics approval was obtained from Southern Cross University's Human Research Ethics Committee.

\section{Recruitment and sample}


All 21 Southern Cross University Tourism and Hospitality Management academics who regularly participated in the continuous curriculum review process were invited to participate. Email invitations were sent to eligible academic staff by an independent external facilitator along with a research information sheet and a consent form. Potential participants were advised that participation was voluntary, that the data would be deidentified, and that they could withdraw from the study at any time.

\section{Interview questions}

The following semi-structured interview questions were used to stimulate discussion:

1. What aspects of the CCR process do you like. Why?

2. What aspects of the CCR process do you dislike? Why?

3. How has the CCR process made you feel?

4. In your opinion does the CCR process have any outcomes? If so, what are they and what is their value to you?

5. Is there anything else that you would like to add about your perceptions of the CCR process?

The responses of academics are designated in the results section by campus ( $\mathrm{L}=$ Lismore; $\mathrm{C}=$ Coffs Harbour, $\mathrm{G}=$ Gold Coast, $\mathrm{S}=$ Sydney) and number. For example L4 indicates the $4^{\text {th }}$ academic at Lismore.

\section{Findings}

Sixteen academics from four campuses (Lismore, Sydney, Gold Coast, Coffs Harbour) were interviewed during three focus groups, which represented $76 \%$ of the 21 academics who regularly participated in the process. Academics from all three curriculum areas taught at Southern Cross University - tourism, hospitality, and conventions and events management participated in the study. The majority of participants were fulltime 
academics employed at the level of Lecturer. A minority of participants held casual or contract positions as lecturers or tutors. Service years ranged from one year to 18 years.

Four major themes regarding the perceived benefits of the process, each with sub themes, emerged from the NVivo thematic data analysis. Participants valued the opportunity the process provided for quality enhancement of the curriculum and anticipated improvements to student learning and the student experience. Participants also valued the changes the process brought to their academic practice, particularly in relation to collaboration, scholarship of teaching, and affective dimensions of being an academic.

'...what we're trying to work towards [is] creating something that is beneficial to the student experience and student performance as well as our own experience and our own performance' $L 4$

In addition concerns were expressed about the facilitation of the process across multiple campuses and the lack of explicit links between the process and outcomes. Illustrative comments from participants can be found in Table 1.

\section{Quality enhancement of the curriculum}

Participants valued the continuous curriculum review process as a collective, systematic evidence-based opportunity to review, record, manage and monitor changes to the whole curriculum over time. Participants valued and understood the relationship between this process and the University's formal course review processes, by 'producing annual reports that then can feed into preparation of materials of whole school reviews ... it is a valuable piece in putting all of that data and information together, that is going to make that bigger process easier.' (L3). 
The process afforded participants an opportunity to get a 'student view' on the curriculum, session by session. It also afforded participants the opportunity to share problems they encountered in individual subjects and determine whether these problems were particular to their subject or shared.

Participants also valued the opportunity the process afforded them to review, monitor and improve student assessment. The collaborative nature of the process meant that student assessment could be reviewed across clusters of subjects for vertical and horizontal alignment of learning outcomes and graduate attributes, overall assessment load, duplications in assessment tasks, logjams in the scheduling of assessment tasks, and omissions and gaps.

Participants reported that the process helped them to keep the curriculum current, 'the units need to be constantly monitored to be updated and remain contemporary (L4)...and this [process] forces you to do [this] (L6)'

\section{Scholarship of teaching and learning}

The term scholarship of teaching describes a continuum of informal and formal activities in which academics engage to improve their teaching. Activities include reflecting on teaching, taking the students' perspective, engaging with pedagogy via teaching and learning literature, talking with peers about teaching and learning, and publishing about teaching and learning. Findings from this study suggest that the process created unanticipated opportunities for a range of activities related to the scholarship of teaching.

Participants valued the process for encouraging a reflective approach to teaching and learning and for providing opportunities to expand research and publication outcomes. 
'I've figured out what I'm doing that is different from my colleagues and I've used that to create journal papers and conference articles because I've realised ... maybe I should write it up and it's been published, so that's great' L5

\section{Collaboration}

Participants valued the collaborative nature of the process and the opportunities it provided for benchmarking with peers, learning from others, identifying common problems and sharing ideas in collegial conversations. Participants also valued the opportunity to develop collegial relationships with University teaching and learning staff, academic support staff and librarians. In some instances these relationships with central University staff resulted in benchmarking opportunities with other schools. Additionally, participants valued the cross-campus communication that created 'a networking of minds on the issues'. Colleagues distributed across multiple campuses sometimes separated by large distances found this aspect of the process beneficial.

\section{Matters of affect}

Participants reported that the process had a positive effect on their feelings about their academic practice and their academic identity. Participants variously reported on feeling valued and included through having their opinion heard, and using the process as a debriefing exercise and a valve to reduce aggravation. Participants who were casual and contract staff reported that the process built confidence and pride through the benchmarking opportunities that accompanied the process, and provided reassurance that problems are sometimes shared by others. Participants also appreciated that they had agency and ownership over the process, which encouraged participation.

\section{Concerns}


Participants reported two major concerns. One concern related to the management and facilitation of meetings using teleconferencing across multiple campuses. 'Generally I am sitting on the other end of a phone line, and it's terribly, terribly boring to sit in a different room ... you can zone out and do your emails...' L5. Participants wanted strong facilitation of meetings across campuses.

The other concern related to the perception by some participants that the link between the process and outcomes was not evident to them. Participants wanted feedback on what was going to be actioned, by whom, and when. Other concerns were the workload commitment that the process demanded, and the accessibility of the process to all casual and contract staff.

\section{Discussion and Conclusions}

This case study offers a unique insight into the perceptions of tourism and hospitality educators at one university about one continuous and collaborative curriculum review process. The findings in this study confirm the findings from studies of similar processes in disciplines and subject areas other than tourism and hospitality.

The study offers new and timely knowledge about one way that tourism and hospitality departments might respond to the current demands being placed upon their curricula (Dredge et al., 2013). National Standards frameworks require curriculum cohesion, yet the curriculum cultures of departments/schools, the individualised and private nature of academic work, multiple delivery sites of the curriculum both on and off shore, and multiple or mixed modes of delivery all pressure the curriculum towards fragmentation rather than cohesion.

The study highlights the often overlooked social and affective dimensions of academic 
life. The profound value of a conversation between academics about teaching, learning and curriculum should not be underestimated. Yet such a simple thing as talking to each other about teaching, learning and the curriculum is not an activity that is typically valued, rewarded or scheduled by departments/schools (Fisher et al., 2003). McCormack \& Kennelly (2011, p. 516) go so far as to call it the 'lost academic practice of groups of teachers regularly talking about learning and teaching'.

The study also highlights the depth of culture change, and the depth and breadth of support at the department level that processes such as these require. Many researchers in this field comment whilst 'the payoff is a curriculum that is current, responsive, proactive, and effective '(Narayan \& Edwards, 2011 p.7), the processes are difficult, resource intensive and time consuming (Dempster et al., 2012; Narayan \& Edwards, 2011). Fisher et al. (2003, p. 775) argue that change must be systemic and must 'move the focus from individual faculty interest, motivation, and activity to collective ownership and understanding of the reform efforts.' 'It needs commitment and resources, such as an institutional culture legitimising innovation, high-level management support for freeing up course teams to work together for substantial periods, specialist facilitators/practitioners and a commitment to evidence-informed curriculum development founded on evaluation of the student experience (Dempster et al., 2012, p.145).

This process required academics to step outside the traditional private space of their teaching and curriculum development and talk with their colleagues about their subject's curriculum, the relationship of their subject to surrounding subjects and to the program curriculum as a whole. Through these semi-structured conversations individual academics gained both a broader view of, and a greater sense of agency over, the program curriculum and their part in it. They learned that a change in one individual part of the 
curriculum affects other parts, which in turn engendered more collective responsibility and custodianship of the whole course. Academics learn to 'see' the course through the eyes of their students - as a whole integrated learning experience rather than a string of disparate and disconnected experiences.

\section{Limitations}

This case study describes one bespoke process of continuous collaborative curriculum review in one tourism and hospitality department within one regional Australian university. The details of the process itself may or may not be useful in other higher education contexts.

The study is limited by a lack of student involvement in the process itself, despite student involvement being a positive characteristic in similar process described in the literature (Bath et al., 2004; Narayan \& Edwards, 2011).

\section{Further research}

The two main areas of concern identified in this study highlight possibilities for future research: firstly how can meaningful academic collaboration across multiple campuses be managed; and secondly, how can continuous curriculum review processes make more explicit links for participating academics between their contributions and overall curriculum outcomes. 


\section{References}

Argyris, C. (1985). Action science concept: Methods and skills for research and intervention. San Francisco: Jossey-Bass.

Barnett, R. \& Coate, K. (2004). Engaging the curriculum in higher education. New York: Open University Press.

Bath, D., Smith, C., Stein, S. \& Swann, R. (2004). Beyond mapping and embedding graduate attributes: Bringing together quality assurance and action learning to create a validated and living curriculum. Higher Education Research \& Development, 23(3), 313328.

Beetham, H. (2009). Synthesis report: Baselining the institutional processes of curriculum design. JISC Institutional Approaches to Curriculum Design Programme.

Retrieved December 1, 2014 from

www.jisc.ac.uk/media/documents/.../designbaselinereport09.doc

Boyatzis, R.E. (1998). Transforming Qualitative Information Thematic Analysis and Code Development. Thousand Oaks: Sage.

Braun, V. \& Clarke, V. (2006). Using thematic analysis in psychology. Qualitative Research in Psychology. 3, 77-101.

Briggs, C. L. (2007). Curriculum collaboration: A key to continuous program renewal. The Journal of Higher Education 78(6), 676-711. 
Deming, W. E. (1982). Quality, productivity, and competitive position. Cambridge, MA: MIT Center for Advanced Engineering Study.

Dempster, J.A., Benfield, G. \& Francis, R. (2012). An academic development model for fostering innovation and sharing in curriculum design. Innovations in Education and Teaching International, 49(2), 135-147.

Dredge, D., Benckendorff, P., Day, M., Gross, M., Walo. M., Weeks, P. \& Whitelaw, P. (2013). Drivers of change in tourism, hospitality and event management education: An Australian perspective. Journal of Hospitality and Tourism Education, 25, 89-102.

Eraut, M. (1994). Developing professional knowledge and competence. London: Falmer.

Fidgeon, P.R. (2010). Tourism education and curriculum design: A time for consolidation and review? Tourism Management. 31: 699-723.

Fisher, D., Fairweather, J. \& Amey, M. (2003). Systemic reform in undergraduate engineering education: The role of collective responsibility. International Journal of Engineering Education, 19(6), 768-776.

Harper, B.J. \& Lattuca, L.R. (2010). Tightening curricula connections: CQI and effective curriculum planning. Research in Higher Education, 51, 505-527.

Hicks, O. (2009). Report on the proposals and expressions of interest from the first call for priority projects grants under the 'Curriculum Renewal' Priority, 2008. Retrieved 
November 24, 2014 from http://www.olt.gov.au/resource-priority-project-curriculumrenewal.

Hubbell, H. \& Gold, N. (2007). The scholarship of curriculum practice and undergraduate program reform: Integrating theory into practice. New Directions for Teaching and Learning, 112, 5-14.

Hughes, J.C. (2007). Supporting curriculum assessment and development: Implications for the faculty role and institutional support. New Directions for Teaching and Learning, $112,107-110$.

Johns, N. \& Henwood, J. (2009). Building reflective practitioners on business programmes: An action research study. Journal of Hospitality, Leisure, Sports and Tourism Education, 8(1), 20-36.

Keogh, J.J., Fourie, W.J., Watson, S. \& Gay, H. (2010). Involving the stakeholders in the curriculum process: A recipe for success? Nurse Education Today, 30, 37-43.

Kirkpatrick, D., \& Kirkpatrick, J. (2006). Evaluating training programs: The four levels. ( $3^{\text {rd }}$ ed.) San Francisco: Berrett-Koehler.

Knight, P. (2006). The professional learning of teachers in higher education. Studies in Higher Education, 31(3), 319-339.

Marlowe, K.F., Wargo, K.A. \& Kelley, K.W. (2012). Peer review of the curriculum as a continuous process of improvement. Currents in Pharmacy Teaching and Learning, 4, 157-164. 
McCormack, C. \& Kennelly, R. (2011). 'We must get together and

really talk ...'. Connection, engagement and safety sustain learning and teaching conversation communities, Reflective Practice: International and Multidisciplinary Perspectives, 12(4), 515-531.

Narayan, B. \& Edwards, S. (2011). Good practice report: Curriculum renewal. Australian Learning and Teaching Council, Australian Government Department of Education, Employment and Workplace Relations. Retrieved November 24, 2014 from http://www.olt.gov.au/resource-curriculum-renewal-2011.

QSR International Limited. (2011). NVivo9 [computer software]. Victoria, Australia: QSR International Limited.

Radloff, A. (2004). Decentralised approaches to education development: supporting quality teaching and learning from within the faculty. In K. Fraser (Ed.), Education development and leadership in higher education. London: Routledge Falmer.

Smith, C., Herbert, D., Robinson, W. \& Watt, K. (2001). Quality assurance through a continuous curriculum review (CCR) strategy: Reflections on a pilot project. Assessment and Evaluation in Higher Education, 26(5), 489- 502.

Stuart, M. (2002). Critical influences on tourism as a subject in UK higher education: Lecturer perspectives. Journal of Hospitality, Leisure, Sport \& Tourism Education, 1(1), 518.

The Glossary of Education Reform. Coherent Curriculum. Retrieved May 19, 2015 from http://edglossary.org/coherent-curriculum/ 
The Quality Assurance Agency for Higher Education. (2008). Subject Benchmark Statement: Hospitality, leisure, sport and tourism. Retrieved May 19, 2015 from http://www.qaa.ac.uk/en/Publications/Documents/Subject-benchmark-statementHospitality-leisure-sport-tourism-2008.pdf

van de Mortel, T. \& Bird, J. (2010). Continuous curriculum review in a Bachelor of Nursing course: Preventing curriculum drift and improving quality. Journal of Nursing Education. 49(10), 592-595.

van de Mortel, T., Bird, J., Holt, J. \& Walo, M. (2012). Quality assurance and quality enhancement of the nursing curriculum: A happy marriage or a recipe for disaster? Journal of Nursing Education and Practice, 2 (3), 110- 119.

Walo, M. (2008). Mapping Graduate Attributes for Tourism and Hospitality, poster paper presented at the 6th Asia-Pacific (APacCHRIE) Conference and THE ICE International Panel of Experts Forum, Perth, WA.

Wegner, E. (1998). Communities of practice: Learning, meaning and identity. Cambridge: Cambridge University Press.

Whitelaw, P.A., Benckendorff, P., Gross, M., Mair, J. and Jose, P. (2015). Setting the Standard: Establishing Tourism, Hospitality and Events Higher Education in Australia, Office for learning and teaching, Sydney, NSW. 
Table 1. Perceived Benefits of the Continuous Curriculum Review Process

\begin{tabular}{|c|c|c|}
\hline $\begin{array}{l}\text { Meta } \\
\text { themes }\end{array}$ & $\begin{array}{l}\text { Sub } \\
\text { themes }\end{array}$ & Comments \\
\hline \multirow[t]{4}{*}{$\begin{array}{l}\text { Quality } \\
\text { enhancement of } \\
\text { the curriculum }\end{array}$} & $\begin{array}{l}\text { A systematic } \\
\text { process }\end{array}$ & $\begin{array}{l}\text { 'it formalises the [end of semester] internal review. 'S2 } \\
\text { 'producing annual reports that then can feed into preparation of } \\
\text { materials of whole school reviews...so it is a valuable piece in putting } \\
\text { all of that data and information together, that is going to make that } \\
\text { bigger process easier.' L3 }\end{array}$ \\
\hline & $\begin{array}{l}\text { An holistic } \\
\text { perspective }\end{array}$ & $\begin{array}{l}\text { 'we get some view of what the semester has been like from the students' } \\
\text { perspective because we sit in a room with all the other people that have } \\
\text { been teaching the same group of students.' L3 } \\
\text { 'You get a sense of being part of the broader picture...'L4 } \\
\text { 'a [way of] understanding what other staff are doing... and if lots of } \\
\text { them are saying [there's a] problem then that alerts me to those issues } \\
\text { which is quite useful...' S2 }\end{array}$ \\
\hline & $\begin{array}{l}\text { Student } \\
\text { assessment }\end{array}$ & $\begin{array}{l}\text { 'I remember in one of the first meetings we realised that we had three } \\
\text { business plans in the same semester for students in third-year!' L5 } \\
\text { 'I think the process has been incredibly beneficial in terms of aligning } \\
\text { assessments so that...[students] have the [assessments] laid out over } \\
\text { several weeks.' L5 }\end{array}$ \\
\hline & $\begin{array}{l}\text { Currency of } \\
\text { content }\end{array}$ & $\begin{array}{l}\text { 'the [subjects] need to be constantly monitored to be updated and } \\
\text { remain contemporary (L4)... } \\
\text { '... and this [process] forces you to do [this.]' L6 }\end{array}$ \\
\hline \multirow[t]{2}{*}{$\begin{array}{l}\text { Scholarship } \\
\text { of teaching }\end{array}$} & $\begin{array}{l}\text { Reflective } \\
\text { practice }\end{array}$ & 'it does make you reflect and look at your work practices.' L4 \\
\hline & $\begin{array}{l}\text { Research \& } \\
\text { publication }\end{array}$ & $\begin{array}{l}\text { 'we've got really, really strong working relationships with Teaching \& } \\
\text { Learning Centre (TLC) and Academic Skills Development Unit (ASDU), } \\
\text { which have led to some research opportunities ... that either directly } \\
\text { or indirectly has come through this process and the relationships that } \\
\text { have been formed.' L3 } \\
\text { 'I've realised ...maybe I should write it up and it's been published, so } \\
\text { that's great.' L5 }\end{array}$ \\
\hline \multirow[t]{2}{*}{ 3. Collaboration } & $\begin{array}{l}\text { From } \\
\text { isolation to } \\
\text { conversation }\end{array}$ & $\begin{array}{l}\text { 'taking that across the broad curriculum view rather than me sitting } \\
\text { in my silo.' C3 } \\
\text { 'the benchmarking thing...it has been incredibly valuable for me' L3 } \\
\text { 'we all come up with some fantastic ideas...and say, 'I teach that in } \\
\text { mine why don't you pick that up in yours and we'll do an assessment,' } \\
\text { you know, so you start having this collegiate idea to teaching students, } \\
\text { it's not about isolating [subjects] it's actually a whole [program] that } \\
\text { you are doing.' S2 } \\
\text { 'everybody is asked what they think even if they're not the [subject] } \\
\text { assessor,'S1 }\end{array}$ \\
\hline & $\begin{array}{l}\text { Multi- } \\
\text { disciplinary } \\
\text { relationships }\end{array}$ & $\begin{array}{l}\text { 'we have improved our relationships I think, out of sight, with teaching } \\
\text { and learning and ASDU.' L3 } \\
\text { 'the library ... did something for us as a direct result of one of these } \\
\text { meetings... that was fantastic.' C2 } \\
\text { 'the benchmarking thing...it has been incredibly valuable for me.' L3 } \\
\text { 'ASDU has been helping very closely on the ground with my particular } \\
\text { first year [subject]...and it's worked really well... feedback from the } \\
\text { students they've said, 'great, great, great' and loved it and really } \\
\text { benefited from it.' L1 }\end{array}$ \\
\hline \multirow[t]{2}{*}{$\begin{array}{l}\text { 4. Matters of } \\
\text { affect }\end{array}$} & Debriefing & $\begin{array}{l}\text { 'I think it's a really good debriefing session.' L2 } \\
\text { 'I find being able to talk about it stops me getting aggravated.' C2 }\end{array}$ \\
\hline & $\begin{array}{l}\text { Building } \\
\text { confidence \& } \\
\text { pride }\end{array}$ & $\begin{array}{l}\text { 'we used the term 'airing your laundry'... The first time you do that you } \\
\text { might think 'Gosh, everyone else has got } 100 \% \text { glowing responses and } \\
\text { one student was unhappy with something that I did!' and then you find } \\
\text { out that actually it's a fairly contemporary situation so that's about }\end{array}$ \\
\hline
\end{tabular}




\begin{tabular}{|c|c|c|}
\hline & & $\begin{array}{l}\text { your own confidence in your own abilities and your own development } \\
\text { too.' L4 } \\
\text { 'it actually gets staff involved who aren't here all the time because we } \\
\text { have lots of casual contracted staff... and at the end of semester they ... } \\
\text { are all in the same room....and maybe something that they've had a bit } \\
\text { of an issue with during the semester ... suddenly is brought out by } \\
\text { somebody else and they feel actually that their problem is sort of } \\
\text { shared with everyone else as well.' S2 } \\
\text { 'I like the fact that we are actually asked our opinion on what we } \\
\text { actually think about something....' S1 } \\
\text { 'Pride in the profession, pride in what you're doing and if you're trying } \\
\text { out something new [you can] tell your colleagues about which actually } \\
\text { makes you feel good.' L5 }\end{array}$ \\
\hline & $\begin{array}{l}\text { Agency \& } \\
\text { ownership }\end{array}$ & $\begin{array}{l}\text { 'I think by us feeling some sort of ownership of the process we can take } \\
\text { it however we want really, if we want it to have much more positive, } \\
\text { immediate outcomes or just to change the structure of the meetings, I } \\
\text { mean we can do it, we're not really tied to something for once that's } \\
\text { been dictated to us, it's exciting.' L3 }\end{array}$ \\
\hline
\end{tabular}

